\section{Evaluation of Heat and Drought as Components of Summer Stress on Tall Fescue Genotypes}

\author{
James W. Cross ${ }^{1,2}$, Stacy A. Bonos, Bingru Huang, and William A. Meyer \\ Department of Plant Biology and Pathology, Rutgers University, Foran Hall, \\ 59 Dudley Road, New Brunswick, NJ 08901
}

Additional index words. drought stress, heat stress, physiology, turfgrass, turf management

\begin{abstract}
Heat and drought are two major abiotic stresses causing a decline in quality in cool-season turfgrasses during the summer. The objectives of this study were 1) to determine whether genotypic variations in turf performance during summer stress in New Jersey is related primarily to heat tolerance or drought tolerance of tall fescue; and 2) to make selections of plants tolerant to summer stress for breeding efforts. Twentyfour tall fescue genotypes exhibiting differential performance during summer months in field conditions (12 summer stress-tolerant and 12 summer stress-sensitive) were selected from the germplasm pool present at the New Jersey Agricultural Experiment Station. Plants of these 24 genotypes were exposed to heat, drought, or heat + drought. There were generally no significant differences in turf quality, photochemical efficiency, relative water content, or electrolyte leakage between summer stress-tolerant and -sensitive genotypes, except in the heat treatment in which the summer stress-tolerant selections performed significantly better. The results indicate that the superior performance of the summer stress-tolerant plants under field conditions is mainly the result of superior heat tolerance.
\end{abstract}

Cool-season turfgrasses exhibit a bimodal growth pattern with most of their growth and development in the spring and fall months and a drastic decline in growth and overall turf quality during the summer months (Turgeon, 2005). The decline in overall turf quality of cool-season grasses during summer months is commonly referred to as summer stress. Summer stress can be broken down into two major components, heat stress and drought stress (Huang et al., 1998a; Jiang and Huang, 2000, 2001b). Although these two stresses often occur simultaneously, that is not always the case. Quantification and comparison of the stress-induced decline caused by each will help better combat the summer decline of cool-season turfgrasses both through best management practices and breeding of improved varieties. The occurrence of dormancy during periods of summer stress has been shown to be a desirable trait that can aid in the long-term survival of turfgrasses (Hopkins and Bhamidimarri, 2009; Malinowski et al., 2005). However, for many turfgrass managers, dormant turf is not an option because of the loss of turf quality and function. Therefore, in this study, dormancy will be considered a negative attribute.

Global focus on environmental sustainability continues to spread and intensify (Jiang

Received for publication 18 June 2013. Accepted for publication 10 Oct. 2013.

${ }^{1}$ Current address: Peak Plant Genetics, 12451 Duckflat Road, Turner, OR 97392.

${ }^{2}$ To whom reprint requests should be addressed; e-mail james.cross@meritel.net. and Huang, 2001b). From 1960 to 2000, there have been increases of $30 \%, 28 \%, 24 \%$, and $26 \%$ for each decade, respectively, in global water consumption (Kirda and Kanber, 1999). These steady increases have caused the worldwide consumption of freshwater in 2000 to be up more than 160\% from 1960 levels (Kirda and Kanber, 1999). If demand for fresh water continues to increase, it is likely that its use for irrigation will become limited to food crops, leaving turf managers with less available water.

Tall fescue [Lolium arundinacea (Schreb.) Darbysh.] has long been considered one of the best-adapted cool-season grasses for hot and dry conditions (Turgeon, 1980). Tall fescue's superior performance during hot a low water use rate like hard fescue (Festuca brevilipa $\mathrm{R}$. Tracey), another drought-tolerant species (Brar and Palazzo, 1995). Conversely, tall fescue has significantly higher water use than many other cool-season turfgrasses and higher water use than several warm-season turfgrasses (Beard, 1989; Biran et al., 1981; Githinji et al., 2009). Tall fescue facilitates its high water use, even during times of drought, through a deep and expansive root system (Carrow, 1996). Its ability to avoid drought conditions by continually having access to water even during prolonged dry periods allows cells to remain turgid and actively growing. In addition, its steady high use of water allows tall fescue to actively cool itself though transpiration cooling. Jiang and Huang (2001b) compared tall fescue with perennial ryegrass (Lolium perenne L.), and found that tall fescue had higher leaf water dry summer months is not a result of it having content while experiencing heat and drought stress compared with perennial ryegrass. They also suggested that tall fescue was cooling itself through transpiration cooling and that this was one of the main factors leading to its superior performance during heat and drought stress. Tall fescue's ability to maintain lower temperatures in its leaf tissue leads to increased membrane stability as well as increased photosynthetic efficiency. Membrane stability and plant photosynthetic efficiency are highly sensitive to elevated cell temperatures (Taiz and Zeiger, 2002).

Cui et al. (2006) compared the photosynthetic performance of two tall fescue genotypes known to have differing levels of heat tolerance. In this study, 'Jaguar 3' (heattolerant) and 'TF 66' (heat-sensitive) were heat-stressed in growth chambers with day/ night temperatures of $35 / 30{ }^{\circ} \mathrm{C}$ for $20 \mathrm{~d}$. They found that maintenance of photosynthesis, more specifically the maintenance of photosystem II and chlorophyll content, was very important in tall fescue's ability to survive during high temperatures. They also found that prevention of cell membrane damage through antioxidant production was strongly correlated with heat tolerance. Wang et al. (2009) similarly subjected 'Jaguar 3' and ' $\mathrm{TF}$ 66 ' to heat stress in growth chambers for $20 \mathrm{~d}$ with day/night temperatures of $35 / 30^{\circ} \mathrm{C}$. The relative growth rate of 'Jaguar 3' decreased by $10 \%$ at Day 20 , whereas the relative growth rate at Day 20 for 'TF 66' decreased by $93.7 \%$. 'Jaguar 3' did not suffer the significant reduction in root-to-shoot ratio compared with 'TF 66'. Leaf and root electrolyte leakage were also significantly less for 'Jaguar 3' (Wang et al., 2009).

Understanding what environmental factors are contributing to the overall decline exhibited by cool-season turfgrasses during summer months would be valuable for proper management of these turfgrass ecosystems. Differentiating heat and drought as components causing this overall decline will allow for management practices tailored to specifically alleviating the particular cause of the decline in summer turf quality. The use of improved varieties capable of maintaining acceptable quality during periods of intense summer stress would be an important tool. With this in mind, this experiment was designed to 1) evaluate diverse tall fescues under heat and drought stress alone and in combination; and 2) to select plants with a high level of summer stress tolerance to be used in future breeding projects.

\section{Materials and Methods}

Plant material. Twenty-four experimental tall fescue genotypes with distinct summer performance were selected from unirrigated space-plant nurseries consisting of over 5000 non-replicated plants at the Rutgers Agricultural Experiment Station in Adelphia, NJ. During the summer of 2010, 24 genotypes were selected; 12 had $95 \%$ to $100 \%$ green tissue and were considered summer stresstolerant genotypes, and 12 had $0 \%$ to $5 \%$ 
green tissue and were considered summer stress-sensitive. To prevent differences in turf performance resulting from the presence or absence of endophytic fungi as described by Elbersen and West (1996) and West (1994), all 24 genotypes were screened for the presence of endophyte and all were found to be endophyte-positive using immunoblot assay kits (ENDO797-3; Agrinostics Ltd. Co., Watkinsville, GA). Three vegetative replicates of each genotype were transferred into plastic pots $(10 \mathrm{~cm}$ diameter $\times 36 \mathrm{~cm}$ deep) filled with a mixture of sterilized soil (fine-loamy-mixed mesic typic hapludult) and sand $(2: 1, \mathrm{v}: \mathrm{v})$. Sixteen pots of each of the 24 genotypes were used for a total of 384 pots.

Plants were grown for $50 \mathrm{~d}$ in a greenhouse with average daily temperatures of $25^{\circ} \mathrm{C}$ and a 14-h photoperiod. Ambient light was supplemented with 400-W high-pressure sodium lights (PL Light Systems, Beamsville, Ontario, Canada) placed $1.5 \mathrm{~m}$ above the plants. Plants were watered biweekly or as soil surface drying was observed in a majority of the pots. Plants were hand-trimmed with scissors two times each week at a height of $7.5 \mathrm{~cm}$. A $16.0 \mathrm{~N}-3.5 \mathrm{P}-5.0 \mathrm{~K}$ water-soluble quick-release fertilizer was applied in two equal applications immediately after, and $25 \mathrm{~d}$ after, transplanting to supply a total of $62.5 \mathrm{~kg} \cdot \mathrm{ha}^{-1}$ of nitrogen.

After plant establishment in the greenhouse, plants were moved to growth chambers. The plants were allowed to acclimate to the chambers for $30 \mathrm{~d}$ before treatments were imposed. During this acclimation period, the chambers were set up to provide a photoperiod of $14 \mathrm{~h}$, photosynthetically active radiation of $500 \mu \mathrm{mol} \cdot \mathrm{m}^{-2} \cdot \mathrm{s}^{-1}, 60 \%$ relative humidity, and day and nighttime temperatures of 25 and $20^{\circ} \mathrm{C}$, respectively. Mowing and irrigation treatments during the acclimation period were identical to the greenhouse grow-in period. Mowing was performed immediately before measurements being taken. Heritage 0.8 TL (a.i. Azoxystrobin) was applied at a rate of $0.64 \mathrm{~mL} \cdot \mathrm{m}^{-2} 7 \mathrm{~d}$ before the start of the treatments and then again on Day 15 to prevent brown patch (Rhizoctonia solani) from infecting the plants.

The experiment was arranged in a randomized complete block design with four replications. Four treatments were imposed: 1) well-watered control (C): all plants were watered to field capacity when soil surface drying was observed in a majority of the plants; 2) heat stress $(H)$ : all plants were watered to field capacity when soil surface drying was observed in a majority of the plants and day and nighttime temperatures of 38 and $33{ }^{\circ} \mathrm{C}$, respectively; 3) drought stress (D): plants received no irrigation and day and nighttime temperatures of 25 and $20{ }^{\circ} \mathrm{C}$, respectively; and 4) heat + drought stress $(\mathrm{H}+\mathrm{D})$ : plants received no irrigation and day and nighttime temperatures of 38 and $33{ }^{\circ} \mathrm{C}$, respectively. All other environmental conditions were the same in all four treatments. Four chambers were used for each treatment. To mitigate chamberrelated variation, the plants and treatments were rotated between the chambers weekly.
Data collection. Measurements of various shoot characteristics were made weekly on each plant starting $7 \mathrm{~d}$ after treatments were initiated. Treatments continued until a majority of the plants receiving the treatment were dormant or until the end of the experiment on Day 30. Termination occurred on Days 14 and 22 for the $\mathrm{H}+\mathrm{D}$ and $\mathrm{D}$ treatments, respectively. Both the $\mathrm{H}$ and $\mathrm{C}$ treatments were maintained for the full $30-\mathrm{d}$ period.

Turf quality (TQ) was rated visually on a 1 to 9 scale of the overall performance of the plant. This rating was based on that of Hays et al. (1991) with slight modifications. A plant receiving a 9 was fully turgid, actively growing, and had no leaf browning or firing; a plant receiving a 1 was completely wilted, not growing, complete leaf browning, and was nearly dead or dormant.

Leaf photochemical efficiency $\left(\mathrm{F}_{\mathrm{v}} / \mathrm{F}_{\mathrm{m}}\right)$ was measured by using a fluorescence induction monitor (Dynamax, Houston, TX) to measure the chlorophyll fluorescence of the leaf tissue. Comparing the maximum fluorescence with the variable level at $690 \mathrm{~nm}$ can be used to estimate the efficiency of photosystem II $\left(F_{\mathrm{v}} 690 \mathrm{~nm} / \mathrm{F}_{\mathrm{m}} 690 \mathrm{~nm}\right)$ (Krause and Weis, 1984; Zhang et al., 2003). Photosystem II is highly sensitive to heat stress and decreases in efficiency as plants become heatstressed (Taiz and Zeiger, 2002).

Membrane stability [electrolyte leakage (EL)] was estimated by measuring leaf cell electrolyte leakage using a variation of the methods described by Blum and Ebercon (1981) and Marcum (1998). Approximately $1 \mathrm{~g}$ of leaf tissue was cut into $1-\mathrm{cm}$ pieces. These leaf sections were then rinsed with distilled deionized water. The leaf sections were placed into centrifuge tubes containing $20 \mathrm{~mL}$ of distilled deionized water before being placed on shaker for $15 \mathrm{~h}$. After this initial incubation, the conductivity of the solution was measured (Model 32; Yellow Spring Instrument Co., Yellow Springs, $\mathrm{OH}$ ) yielding the initial conductivity $\left(\mathrm{C}_{\mathrm{i}}\right)$. The tubes were then autoclaved for $30 \mathrm{~min}$ at $120^{\circ} \mathrm{C}$ to kill the plant tissue. The tubes were allowed to cool and placed on a shaker for $15 \mathrm{~h}$. After the second incubation, the conductivity of the solution was again measured, yielding the maximum conductivity $\left(\mathrm{C}_{\max }\right)$. The EL was then calculated using the equation: $\left[\% \mathrm{EL}=\left(\mathrm{C}_{\mathrm{i}}\right) /\left(\mathrm{C}_{\max }\right) \cdot 100\right]$.

Leaf relative water content (RWC), a percentage measure of the amount of water in fresh leaves compared with the amount of water of the leaves when they are fully turgid, was measured using the protocol described by Barrs and Weatherley (1962). Approximately $0.3 \mathrm{~g}$ of fully expanded leaf tissue was collected and weighed to obtain the fresh weight $\left(\mathrm{W}_{\mathrm{F}}\right)$; the leaf tissue was then soaked in distilled water for $24 \mathrm{~h}$. After this incubation, the leaf tissue was removed from the water and any free surface water was removed using a paper towel before they were weighed again, yielding the turgid weight $\left(\mathrm{W}_{\mathrm{T}}\right)$. After this weighing, the leaves were dried for $48 \mathrm{~h}$ in a drying oven at $85^{\circ} \mathrm{C}$ before the dry weight $\left(\mathrm{W}_{\mathrm{D}}\right)$ was determined.
The leaf RWC was then calculated using the equation: $\left\{\% \mathrm{RWC}=\left[\left(\mathrm{W}_{\mathrm{F}}\right) /\left(\mathrm{W}_{\mathrm{D}}\right) /\left[\left(\mathrm{W}_{\mathrm{T}}\right) /\right.\right.\right.$ $\left.\left.\left(\mathrm{W}_{\mathrm{D}}\right)\right] \cdot 100\right\}$.

Volumetric soil water content (SWC) measurements were also taken weekly on all plants at $20-\mathrm{cm}$ depth using time-domain reflectometry (Soil Moisture Equipment, Santa Barbara, CA).

\section{Results and Discussion}

Summer stress-tolerant genotypes did not exhibit significant differences from the summer stress-sensitive genotypes under the $\mathrm{H}+\mathrm{D}$, D, or $\mathrm{C}$ treatment for any of the parameters measured with these exceptions: TQ in Weeks 1-4 of the C treatment, RWC in Week 3 of the D treatment, and EL and RWC in Week 4 of the $\mathrm{C}$ treatment. When comparing these two groups in the heat stress treatment, summer stress-tolerant genotypes performed significantly better than those selected as summer stress-sensitive in TQ, $\mathrm{F}_{\mathrm{v}} / \mathrm{F}_{\mathrm{m}}, \mathrm{RWC}$, and EL (Fig. 1). The superior performance of the clones selected as summer stress-tolerant in only the heat stress chamber suggests that it is possible that the superior performance of these clones in the field was a result of their high level of heat tolerance.

Plants receiving the $\mathrm{H}+\mathrm{D}$ treatment declined most rapidly in all measurements (Tables 1-3). These plants declined to the point that treatment had to be stopped after $14 \mathrm{~d}$ because a majority of the plants had gone dormant and further treatment would have likely led to plant death. The plants receiving the drought treatment deteriorated more quickly than the heat-treated plants for photochemical efficiency as well as EL (Table 3). These plants declined to a level at which a majority of the plants were dormant after $22 \mathrm{~d}$ and at this point, the treatment was stopped to prevent complete death. When comparing the deterioration of the plants receiving the different treatments, the decline for all response variables taken was similar with the decline being most rapid for the $\mathrm{H}+\mathrm{D}$-treated plants followed by the plants receiving either the drought or heat treatment. These results supported the findings of Jiang and Huang $(2000,2001 b)$ in that $H+D$ caused a more rapid overall decline than either of the stresses alone. The decrease in average RWC and increase in average EL were significantly more rapid in the drought treatment compared with the heat treatment. This agrees with the findings of Jiang and Huang (2001a) that tall fescue had a more rapid drop in RWC under drought stress than under heat stress. In this study, there was a significantly more rapid decline in the RWC of plants subjected to drought stress alone when compared with plants receiving the heat treatment. Various factors likely led to the rapid decline of the drought-treated plants in this study, including limited rooting depth, low relative humidity, and constant airflow, among others. Restriction of rooting can have large effects on the survival of tall fescue during drought stress (Carrow, 1996; Huang and Gao, 2000). 
A

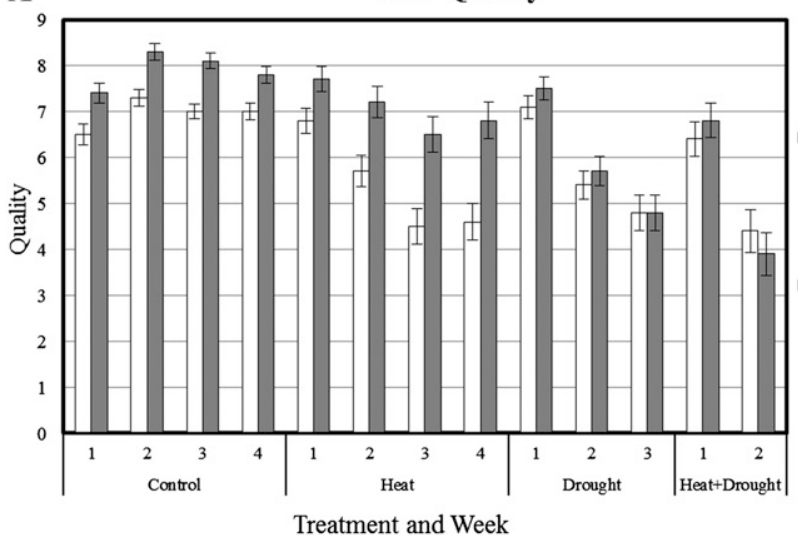

C

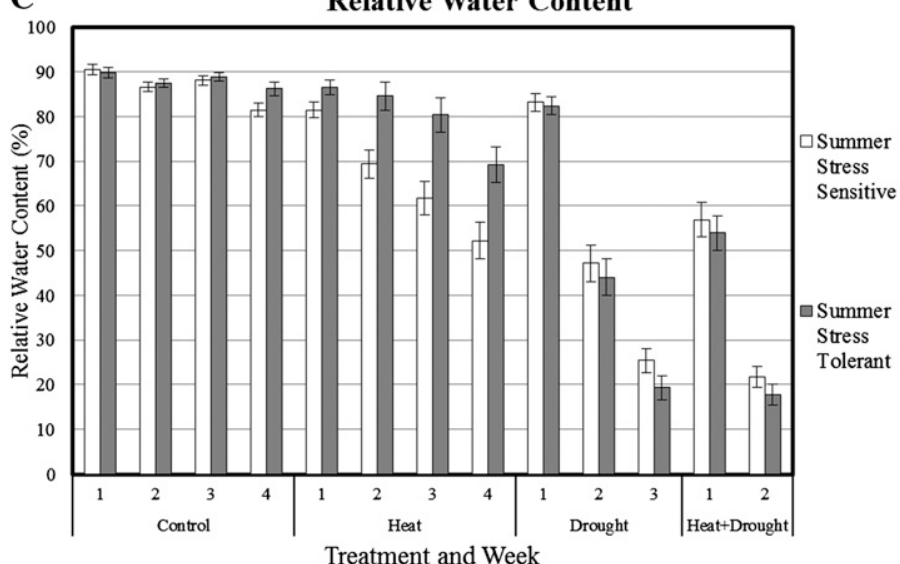

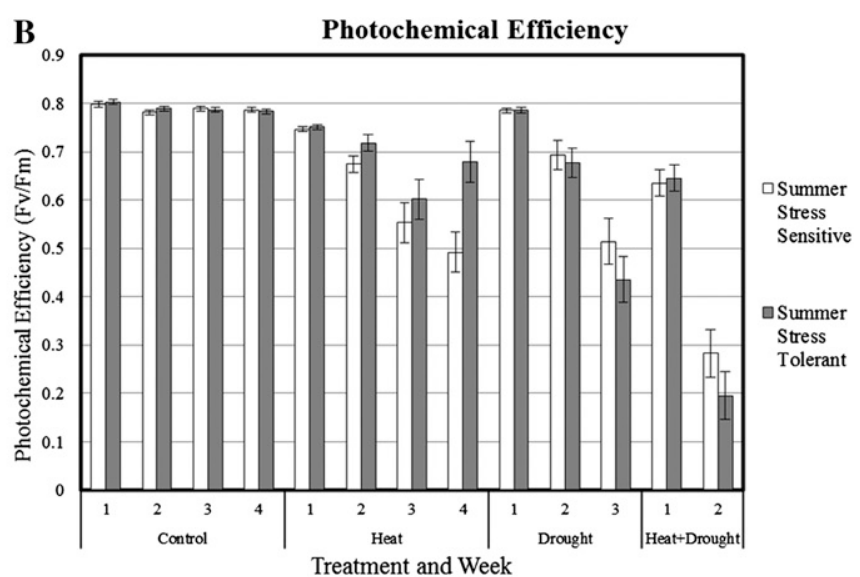

D

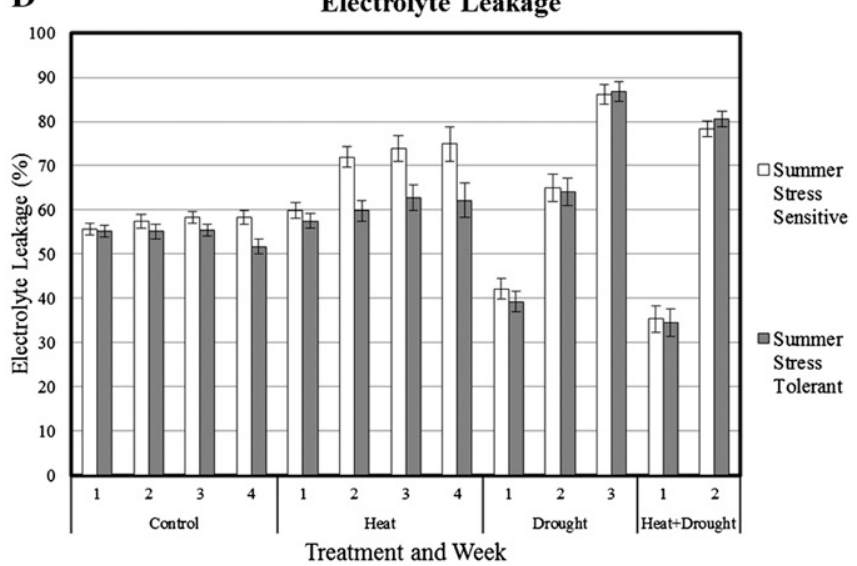

Fig. 1. (A) Turf quality: visual rating on a 1 to 9 scale, (B) photochemical efficiency: efficiency of PSII, (C) relative water content: water content of leaf tissue, and (D) electrolyte leakage: measure of membrane stability. Comparison of summer stress-tolerant and -sensitive tall fescue genotypes evaluated under heat, drought, heat, and drought and control treatments in a growth chamber. Error bars indicate least significant difference (LSD) values $(P=0.05)$. The treatment and rating week in which the data were taken are shown on the $\mathrm{x}$-axis.

Table 1. Quality ratings (1 to 9 visual ratings scale) of tall fescue genotypes evaluated under heat, drought, heat and drought, and control treatments in a growth chamber. ${ }^{2}$

\begin{tabular}{|c|c|c|c|c|c|c|c|c|c|c|c|c|c|c|}
\hline \multirow{2}{*}{$\begin{array}{l}\text { Field } \\
\text { rating }\end{array}$} & \multirow[b]{2}{*}{ Clone } & \multicolumn{4}{|c|}{ Control } & \multicolumn{4}{|c|}{ Heat } & \multicolumn{3}{|c|}{ Drought } & \multicolumn{2}{|c|}{ Heat + drought } \\
\hline & & Week 1 & Week 2 & Week 3 & Week 4 & Week 1 & Week 2 & Week 3 & Week 4 & Week 1 & Week 2 & Week 3 & Week 1 & Week 2 \\
\hline $\mathrm{T}$ & 5 & 8.5 & 9.0 & 9.0 & 8.0 & 8.3 & 7.8 & 7.3 & 7.8 & 8.8 & 5.8 & 5.0 & 8.3 & 3.8 \\
\hline $\mathrm{T}$ & 9 & 8.3 & 8.8 & 8.0 & 7.5 & 6.5 & 5.8 & 5.3 & 6.5 & 6.8 & 4.5 & 3.5 & 5.3 & 2.3 \\
\hline $\mathrm{T}$ & 10 & 7.5 & 8.8 & 8.5 & 8.8 & 7.5 & 7.0 & 6.5 & 7.3 & 7.8 & 7.0 & 5.3 & 8.3 & 6.0 \\
\hline $\mathrm{T}$ & 11 & 7.3 & 7.5 & 8.0 & 7.0 & 7.8 & 6.5 & 6.0 & 6.5 & 7.3 & 4.0 & 2.8 & 3.8 & 1.0 \\
\hline $\mathrm{T}$ & 16 & 6.5 & 7.8 & 7.8 & 7.5 & 7.0 & 6.3 & 5.5 & 6.8 & 8.0 & 7.3 & 6.3 & 8.8 & 4.8 \\
\hline $\mathrm{T}$ & 17 & 5.8 & 7.5 & 6.5 & 6.3 & 7.3 & 7.5 & 6.8 & 6.3 & 7.0 & 5.0 & 4.5 & 7.0 & 4.8 \\
\hline $\mathrm{T}$ & 19 & 7.5 & 7.3 & 7.0 & 7.3 & 7.8 & 7.3 & 6.0 & 5.8 & 7.3 & 4.5 & 3.8 & 4.8 & 2.8 \\
\hline $\mathrm{S}$ & 1 & 6.3 & 6.8 & 6.5 & 7.0 & 4.8 & 3.5 & 1.3 & 1.3 & 6.8 & 4.8 & 3.8 & 6.8 & 4.8 \\
\hline $\mathrm{S}$ & 2 & 6.0 & 7.5 & 7.0 & 7.0 & 7.8 & 7.0 & 6.5 & 6.8 & 7.5 & 5.0 & 4.0 & 4.8 & 3.0 \\
\hline $\mathrm{S}$ & 4 & 8.0 & 8.3 & 7.8 & 7.3 & 7.3 & 7.0 & 4.5 & 4.5 & 8.5 & 5.8 & 5.5 & 6.8 & 4.5 \\
\hline $\mathrm{S}$ & 8 & 5.3 & 6.3 & 7.0 & 7.5 & 6.3 & 3.3 & 1.0 & 1.3 & 6.5 & 7.5 & 7.8 & 8.0 & 8.5 \\
\hline S & 22 & 6.5 & 7.3 & 6.5 & 6.8 & 7.5 & 6.5 & 5.3 & 5.0 & 6.5 & 6.5 & 5.8 & 7.3 & 4.8 \\
\hline $\mathrm{S}$ & 23 & 4.8 & 6.0 & 5.8 & 6.0 & 4.3 & 2.8 & 1.5 & 2.0 & 6.8 & 6.0 & 6.0 & 7.5 & 5.0 \\
\hline $\mathrm{S}$ & 24 & 6.3 & 7.0 & 7.3 & 7.0 & 5.8 & 4.5 & 3.3 & 3.0 & 6.3 & 5.8 & 6.3 & 6.8 & 5.3 \\
\hline \multicolumn{2}{|c|}{ LSD $P=0.05$} & 1.1 & 0.9 & 0.8 & 1.0 & 1.4 & 1.6 & 1.7 & 1.8 & 1.5 & 1.6 & 2.0 & 2.0 & 2.5 \\
\hline
\end{tabular}

${ }^{\mathrm{z}}$ Field rating signifies plants selected under field conditions as summer stress-tolerant (T) or summer stress-sensitive (S). LSD $=$ least significant difference. 
Table 2. Relative water content readings (percent of water in leaves compared with fully turgid leaves) of tall fescue genotypes evaluated under heat, drought, heat and drought, and control treatments in a growth chamber. ${ }^{z}$

\begin{tabular}{|c|c|c|c|c|c|c|c|c|c|c|c|c|c|c|}
\hline \multirow{2}{*}{$\begin{array}{l}\text { Field } \\
\text { rating }\end{array}$} & \multirow[b]{2}{*}{ Clone } & \multicolumn{4}{|c|}{ Control } & \multicolumn{4}{|c|}{ Heat } & \multicolumn{3}{|c|}{ Drought } & \multicolumn{2}{|c|}{ Heat + drought } \\
\hline & & Week 1 & Week 2 & Week 3 & Week 4 & Week 1 & Week 2 & Week 3 & Week 4 & Week 1 & Week 2 & Week 3 & Week 1 & Week 2 \\
\hline $\mathrm{T}$ & 3 & 91.7 & 88.5 & 87.6 & 85.6 & 84.2 & 89.0 & 78.9 & 76.2 & 85.0 & 25.2 & 15.1 & 37.0 & 11.8 \\
\hline $\mathrm{T}$ & 5 & 93.9 & 88.1 & 89.4 & 87.9 & 90.1 & 86.1 & 82.6 & 71.2 & 87.2 & 33.6 & 16.2 & 52.1 & 11.9 \\
\hline $\mathrm{T}$ & 6 & 93.1 & 90.1 & 90.9 & 90.5 & 87.9 & 86.8 & 72.4 & 66.2 & 87.2 & 81.5 & 41.1 & 78.5 & 32.9 \\
\hline $\mathrm{T}$ & 7 & 90.5 & 88.5 & 91.5 & 86.8 & 84.4 & 84.0 & 84.8 & 68.1 & 85.9 & 36.7 & 17.3 & 53.8 & 11.3 \\
\hline $\mathrm{T}$ & 9 & 88.2 & 82.5 & 86.2 & 83.3 & 82.3 & 71.9 & 65.1 & 58.5 & 80.5 & 29.7 & 12.9 & 38.9 & 13.2 \\
\hline $\mathrm{T}$ & 10 & 88.0 & 85.7 & 91.7 & 88.4 & 87.0 & 87.3 & 85.7 & 75.5 & 86.8 & 61.0 & 23.5 & 73.7 & 13.0 \\
\hline $\mathrm{T}$ & 11 & 85.4 & 88.6 & 83.7 & 82.7 & 87.3 & 86.0 & 78.8 & 64.6 & 75.7 & 14.7 & 10.1 & 24.7 & 9.8 \\
\hline $\mathrm{T}$ & 12 & 91.9 & 89.3 & 87.3 & 88.6 & 91.3 & 88.5 & 82.1 & 65.5 & 87.7 & 60.5 & 22.6 & 72.4 & 25.1 \\
\hline $\mathrm{T}$ & 14 & 90.1 & 86.6 & 89.7 & 90.5 & 87.3 & 82.8 & 86.2 & 74.2 & 79.9 & 35.8 & 15.7 & 47.7 & 12.4 \\
\hline $\mathrm{T}$ & 16 & 89.4 & 87.4 & 89.6 & 77.4 & 86.1 & 85.0 & 79.1 & 72.6 & 73.0 & 67.1 & 22.5 & 69.9 & 18.1 \\
\hline $\mathrm{T}$ & 17 & 94.6 & 88.3 & 92.8 & 87.5 & 86.8 & 87.7 & 87.9 & 71.6 & 84.3 & 49.7 & 22.3 & 56.6 & 14.9 \\
\hline $\mathrm{T}$ & 19 & 89.0 & 85.4 & 85.7 & 85.7 & 83.9 & 80.0 & 81.1 & 66.5 & 75.1 & 32.1 & 13.1 & 41.9 & 15.8 \\
\hline S & 1 & 86.1 & 86.1 & 89.8 & 78.4 & 78.5 & 42.1 & 24.5 & 24.4 & 82.2 & 46.9 & 18.4 & 58.0 & 26.9 \\
\hline $\mathrm{S}$ & 2 & 95.1 & 87.1 & 90.8 & 80.9 & 88.2 & 83.3 & 85.9 & 78.8 & 85.8 & 41.4 & 18.8 & 41.1 & 15.4 \\
\hline $\mathrm{S}$ & 4 & 93.8 & 91.3 & 90.3 & 89.7 & 91.2 & 76.6 & 65.7 & 56.1 & 89.1 & 60.9 & 25.3 & 60.1 & 16.1 \\
\hline $\mathrm{S}$ & 8 & 93.0 & 83.7 & 92.6 & 84.2 & 74.4 & 38.1 & 23.6 & 19.9 & 76.8 & 73.5 & 56.8 & 85.5 & 52.0 \\
\hline $\mathrm{S}$ & 13 & 89.3 & 87.3 & 85.9 & 85.0 & 82.9 & 81.8 & 76.7 & 68.5 & 79.7 & 30.9 & 16.6 & 47.8 & 22.3 \\
\hline $\mathrm{S}$ & 15 & 90.0 & 85.6 & 86.5 & 80.6 & 82.8 & 77.5 & 68.1 & 53.3 & 83.3 & 33.3 & 15.5 & 48.4 & 15.2 \\
\hline $\mathrm{S}$ & 18 & 88.7 & 84.8 & 82.5 & 73.5 & 89.2 & 76.2 & 79.3 & 74.1 & 77.0 & 16.8 & 10.8 & 31.4 & 13.7 \\
\hline S & 20 & 89.5 & 84.2 & 88.4 & 85.3 & 81.5 & 83.3 & 78.2 & 73.6 & 85.3 & 33.5 & 17.5 & 47.6 & 13.0 \\
\hline $\mathrm{S}$ & 21 & 86.2 & 91.2 & 89.0 & 85.0 & 81.1 & 86.2 & 66.7 & 57.6 & 81.2 & 44.6 & 19.0 & 63.2 & 15.2 \\
\hline $\mathrm{S}$ & 22 & 91.7 & 88.7 & 90.4 & 82.1 & 84.4 & 83.1 & 83.9 & 55.4 & 87.4 & 59.7 & 37.3 & 63.7 & 24.1 \\
\hline $\mathrm{S}$ & 23 & 81.2 & 85.0 & 88.6 & 69.3 & 59.5 & 49.8 & 36.2 & 26.0 & 83.6 & 61.3 & 37.7 & 62.9 & 22.1 \\
\hline S & 24 & 92.1 & 84.8 & 82.4 & 84.0 & 84.1 & 54.5 & 52.7 & 39.2 & 74.9 & 62.8 & 31.3 & 70.6 & 24.5 \\
\hline$\underline{\operatorname{LSD} P}$ & 0.05 & 7.6 & 6.6 & 6.7 & 9.7 & 9.5 & 13.8 & 16.0 & 22.0 & 13.8 & 15.6 & 12.7 & 19.2 & 12.7 \\
\hline
\end{tabular}

${ }^{\mathrm{z}}$ Field rating signifies plants selected under field conditions as summer stress-tolerant (T) or summer stress-sensitive (S). LSD $=$ least significant difference.

Table 3. Electrolyte leakage readings (\%) of tall fescue genotypes evaluated under heat, drought, heat and drought, and control treatments in a growth chamber. ${ }^{z}$

\begin{tabular}{|c|c|c|c|c|c|c|c|c|c|c|c|c|c|c|}
\hline \multirow{2}{*}{$\begin{array}{l}\text { Field } \\
\text { rating }\end{array}$} & \multirow[b]{2}{*}{ Clone } & \multicolumn{4}{|c|}{ Control } & \multicolumn{4}{|c|}{ Heat } & \multicolumn{3}{|c|}{ Drought } & \multicolumn{2}{|c|}{ Heat + drought } \\
\hline & & Week 1 & Week 2 & Week 3 & Week 4 & Week 1 & Week 2 & Week 3 & Week 4 & Week 1 & Week 2 & Week 3 & Week 1 & Week 2 \\
\hline $\mathrm{T}$ & 3 & 52.1 & 57.0 & 53.7 & 64.0 & 57.4 & 56.5 & 58.7 & 59.5 & 37.9 & 72.3 & 93.7 & 47.6 & 81.8 \\
\hline $\mathrm{T}$ & 5 & 60.0 & 55.3 & 49.7 & 51.7 & 53.6 & 58.8 & 53.4 & 53.2 & 35.9 & 54.4 & 93.9 & 29.7 & 81.4 \\
\hline $\mathrm{T}$ & 6 & 58.2 & 54.9 & 57.6 & 49.4 & 52.1 & 63.6 & 70.5 & 65.8 & 42.3 & 57.7 & 67.6 & 21.2 & 64.9 \\
\hline $\mathrm{T}$ & 7 & 55.7 & 52.6 & 62.0 & 50.4 & 56.9 & 52.7 & 56.4 & 57.7 & 40.7 & 68.0 & 85.8 & 39.1 & 82.6 \\
\hline $\mathrm{T}$ & 9 & 55.8 & 62.4 & 52.3 & 51.8 & 68.4 & 66.4 & 71.6 & 96.5 & 41.4 & 69.1 & 89.8 & 33.0 & 82.9 \\
\hline $\mathrm{T}$ & 10 & 52.5 & 59.9 & 55.9 & 46.9 & 58.0 & 62.2 & 69.4 & 61.0 & 35.4 & 57.1 & 83.9 & 25.2 & 86.9 \\
\hline $\mathrm{T}$ & 11 & 57.0 & 58.3 & 58.4 & 51.9 & 60.4 & 64.3 & 64.3 & 62.2 & 39.9 & 84.0 & 98.4 & 69.3 & 83.3 \\
\hline $\mathrm{T}$ & 12 & 52.0 & 49.7 & 51.8 & 48.9 & 54.0 & 55.1 & 58.5 & 54.6 & 34.5 & 52.8 & 71.3 & 22.9 & 72.2 \\
\hline $\mathrm{T}$ & 14 & 57.6 & 50.0 & 52.8 & 45.4 & 60.9 & 50.5 & 58.7 & 55.1 & 39.9 & 68.4 & 93.5 & 29.6 & 86.0 \\
\hline $\mathrm{T}$ & 16 & 57.4 & 55.2 & 61.9 & 58.5 & 56.2 & 63.9 & 69.1 & 59.6 & 42.0 & 56.0 & 89.4 & 27.8 & 83.7 \\
\hline $\mathrm{T}$ & 17 & 50.8 & 46.6 & 49.5 & 51.4 & 59.2 & 55.6 & 58.2 & 60.0 & 38.6 & 58.8 & 81.1 & 21.9 & 77.5 \\
\hline $\mathrm{T}$ & 19 & 52.5 & 59.6 & 58.8 & 50.5 & 52.8 & 67.5 & 64.8 & 60.6 & 41.8 & 70.5 & 94.2 & 46.4 & 83.0 \\
\hline $\mathrm{S}$ & 1 & 56.4 & 61.6 & 62.9 & 61.6 & 64.4 & 89.1 & 98.8 & 98.0 & 49.6 & 56.5 & 89.0 & 32.9 & 77.5 \\
\hline $\mathrm{S}$ & 2 & 57.4 & 53.9 & 58.4 & 61.1 & 55.7 & 61.7 & 62.1 & 55.8 & 37.3 & 72.2 & 91.8 & 45.4 & 83.3 \\
\hline $\mathrm{S}$ & 4 & 56.1 & 55.1 & 51.9 & 44.6 & 49.9 & 61.5 & 68.7 & 76.6 & 35.4 & 52.5 & 72.0 & 33.3 & 77.8 \\
\hline $\mathrm{S}$ & 8 & 51.0 & 55.8 & 46.9 & 55.1 & 57.3 & 93.6 & 99.1 & 97.7 & 43.2 & 53.7 & 68.2 & 31.7 & 61.8 \\
\hline $\mathrm{S}$ & 13 & 50.8 & 51.9 & 53.0 & 56.9 & 58.2 & 68.2 & 71.3 & 52.1 & 36.8 & 89.3 & 88.3 & 37.1 & 78.4 \\
\hline $\mathrm{S}$ & 15 & 58.2 & 59.9 & 61.3 & 62.9 & 66.4 & 67.8 & 65.8 & 69.0 & 48.5 & 65.2 & 93.8 & 44.0 & 84.0 \\
\hline $\mathrm{S}$ & 18 & 60.5 & 64.5 & 63.1 & 62.5 & 63.2 & 65.1 & 59.4 & 60.1 & 39.5 & 77.5 & 98.5 & 51.2 & 79.1 \\
\hline $\mathrm{S}$ & 20 & 52.9 & 54.3 & 58.5 & 57.7 & 61.4 & 59.3 & 55.5 & 56.1 & 37.9 & 65.8 & 89.1 & 34.6 & 85.8 \\
\hline $\mathrm{S}$ & 21 & 58.5 & 59.6 & 66.0 & 60.2 & 60.8 & 73.0 & 73.6 & 83.7 & 45.1 & 69.8 & 95.0 & 28.7 & 87.9 \\
\hline $\mathrm{S}$ & 22 & 50.9 & 52.2 & 55.1 & 49.6 & 54.7 & 57.3 & 58.3 & 70.5 & 42.2 & 53.0 & 79.3 & 22.5 & 72.6 \\
\hline $\mathrm{S}$ & 23 & 56.5 & 61.8 & 62.1 & 75.6 & 60.7 & 92.6 & 93.8 & 93.7 & 43.1 & 62.6 & 83.1 & 35.3 & 74.5 \\
\hline $\mathrm{S}$ & 24 & 57.3 & 58.1 & 60.5 & 52.0 & 65.8 & 74.2 & 79.3 & 86.5 & 46.9 & 62.5 & 84.6 & 26.9 & 76.5 \\
\hline$\underline{\operatorname{LSD} P}=$ & 0.05 & 9.2 & 10.9 & 7.8 & 9.4 & 11.5 & 11.0 & 13.5 & 21.4 & 17.6 & 19.3 & 10.7 & 16.3 & 9.5 \\
\hline
\end{tabular}

${ }^{\mathrm{z} F i e l d ~ r a t i n g ~ s i g n i f i e s ~ p l a n t s ~ s e l e c t e d ~ u n d e r ~ f i e l d ~ c o n d i t i o n s ~ a s ~ s u m m e r ~ s t r e s s-t o l e r a n t ~(T) ~ o r ~ s u m m e r ~ s t r e s s-s e n s i t i v e ~(S) . ~}$ LSD $=$ least significant difference.

There was a great deal of variation in overall performance of clones within treatments as well as the performance of single clones between treatments; this variation is consistent with the diversity of tall fescues shown by Carrow (1996). Clone TF-8, which was a top-performing clone in the $\mathrm{D}$ and the
$\mathrm{H}+\mathrm{D}$ treatment, was one of the worst performing clones in heat stress treatment. Although being the top-performing clone in the $\mathrm{D}$ and $\mathrm{H}+\mathrm{D}$ treatments, TF- 8 also had the highest volumetric soil water content in the final rating date for each of these treatments at $4.30 \%$ and $4.75 \%$, respectively. These readings are significantly higher than the average of all other clones at these two dates, which were $3.25 \%$ in the $\mathrm{D}$ treatment and $3.21 \%$ in the $\mathrm{H}+\mathrm{D}$-treated plants. This suggests that clone TF-8's superior performance in these two treatments is a result of its lower water use. Further evidence to support this 
hypothesis is evident from the observation of the performance of TF-8 in the $\mathrm{H}$ treatment. In the $\mathrm{H}$ treatment, where TF- 8 was one of the lowest performing clones, it had very high soil moisture ratings. On the final rating date of the heat treatment, TF- 8 had soil volumetric water content of $23.38 \%$. This was significantly higher than the average for all other plants, which was $16.80 \%$. In this study, all plants receiving a particular treatment were irrigated when a majority of the pots in that treatment had noticeable soil surface drying. It is likely that TF-8 suffered detrimental effects of having too much water, which can be significantly more detrimental when it occurs in conjunction with high temperatures (Huang et al., 1998b). The converse of TF-8 is TF-3. Clone TF-3 was one of the topperforming clones in the $\mathrm{H}$ treatment but was near the bottom in the $\mathrm{D}$ and $\mathrm{H}+\mathrm{D}$ treatments (Tables 1-3). It had one of the lowest volumetric SWC of any clone in the $\mathrm{C}, \mathrm{H}$, $\mathrm{D}$, and $\mathrm{H}+\mathrm{D}$ treatments on their final measurement days. It is likely that TF-3 had high water use. This supports the findings of Jiang and Huang (2001b) that plants with higher water use can perform better in high heat because of high levels of transpirational cooling. This is also consistent with the findings of Bowman and Macaulay (1991) that showed significant intraspecific variation in the water use of numerous tall fescue varieties. Intraspecific variation in water use has also been shown to occur in kentucky bluegrass (Poa pratensis L.) (Bonos and Murphy, 1999; Ebdon et al., 1998).

Clone TF-8 was selected as a summer stress-sensitive clone under field conditions. Although it did perform well, as discussed earlier, in the $\mathrm{D}$ and $\mathrm{H}+\mathrm{D}$ treatments, it is suspected that this was a result of its lower water use rate, which meant it had water available to it for a longer period of time during the dry-down. This is consistent with the findings of Carrow (1996) and Huang and Gao (2000) that deep root length density, which allows for a high evapotranspiration rate under drought, is more important to tall fescue's overall resistance to summer stress than having a normally low water use rate. A low baseline evapotranspiration rate has also been shown not to be a reliable indicator of overall drought tolerance; instead, factors such as rooting depth are more important to the overall drought tolerance in other species such as kentucky bluegrass (Bonos and Murphy, 1999; Ebdon and Kopp, 2004; Perdomo et al., 1996). In contrast, TF-3 was selected as summer stress-tolerant under field conditions. This can likely be attributed to the high level of heat tolerance that it exhibited in the field as a result of its ability to transpire at high levels even during periods of drought because of deep root systems as are found in various tall fescues (Huang and Gao, 2000).

Clones TF-5, TF-6, and TF-10 were selected for performing well in one or multiple chambers and therefore have been selected to be used in future breeding projects. Clone TF-5 was selected for having the highest quality in the fourth week of the $\mathrm{H}$ treatment when it rated a 7.8. Clone TF- 6 was selected for performing well in the $\mathrm{D}$ and $\mathrm{H}+\mathrm{D}$ treatments where it received a 7.8 and 7.3 quality rating, respectively, in their final rating dates. Although TF-10 did not perform extremely well in any of the treatments, it was selected for its consistent, above average final quality ratings of 7.3, 5.3, and 6.0 in the $\mathrm{H}, \mathrm{D}$, and $\mathrm{H}+\mathrm{D}$ treatments, respectively.

Correlation analyses between TQ and EL, RWC, and photochemical efficiency were performed on all clones in the H, D, and $\mathrm{H}+\mathrm{D}$ treatments. Electrolyte leakage, RWC, and photochemical efficiency each correlated well with TQ ratings in each of the three treatments. Relative water content had the strongest correlation with TQ ratings in the $\mathrm{H}, \mathrm{D}$, and $\mathrm{H}+\mathrm{D}$ treatments with $r$ values of $r=0.87, r=0.76$, and $r=0.73$, respectively. The weakest correlations with TQ observed in each chamber were with EL in the $\mathrm{H}$ and $\mathrm{H}+\mathrm{D}$ treatments and photochemical efficiency in the $\mathrm{D}$ treatment with $r$ values of $r=-0.75, r=-0.52$, and $r=0.62$, respectively.

In summary, the summer decline of tall fescue plants during the hot dry summer of 2010 in Adelphia, NJ, was likely significantly affected by high temperatures. Plants that were able to survive that summer were likely able to do so because of a higher level of heat tolerance than others that went dormant or died. The fact that the plants selected as summer stress-tolerant did not perform significantly better in the $\mathrm{D}$ and $\mathrm{H}+\mathrm{D}$ treatments is likely an artifact of this experiment being performed ex situ in growth chambers where it is difficult to truly match in situ field conditions. The poor performance of TF-8 in the heat treatment was most likely the result of its becoming overwatered as a result of its comparatively low water use. Clones TF-5, TF- 6 , and TF-10 have been selected as a result of their overall high performance in all treatments to be used for future summer stress tolerance breeding projects that will work to provide turf managers with turfgrasses that are able to provide a high level of overall TQ during summer months without requiring supplemental irrigation.

\section{Literature Cited}

Barrs, H.D. and P.E. Weatherley. 1962. A reexamination of the relative turgidity techniques for estimating water deficits in leaves. Aust. J. Biol. Sci. 15:413-428.

Beard, J.B. 1989. Turfgrass water stress: Drought resistance components, physiological mechanisms, and species-genotype diversity. Keynote address, International Turfgrass Research Conference, Tokyo, Japan, 31 July to 6 Aug.

Biran, I., B. Bravdo, I. Bishkin-Harav, and E. Rawitz. 1981. Water consumption and growth rate of 11 turfgrasses as affected by mowing height, irrigation frequency, and soil moisture. Agron. J. 72:89-90.

Blum, A. and A. Ebercon. 1981. Cell membrane stability as a measurement of drought and heat tolerance in wheat. Crop Sci. 21:4347.
Bonos, S.A. and J.A. Murphy. 1999. Growth responses and performance of kentucky bluegrass under summer stress. Crop Sci. 39:770774.

Bowman, D.C. and L. Macaulay. 1991. Comparative evapotranspiration rates of tall fescue cultivars. HortScience 26:122-123.

Brar, G.S. and A.J. Palazzo. 1995. Tall and hard fescue responses to periodic soil water deficits. J. Agron. Crop Sci. 175:221-229.

Carrow, R.N. 1996. Drought avoidance characteristics of diverse tall fescue cultivars. Crop Sci. 36:371-377.

Cui, L., J. Li, Y. Fan, S. Xu, and Z. Zhang. 2006. High temperature effects on photosynthesis, PSII functionality and antioxidant activity of two Festuca arundinacea cultivars with different heat susceptibility. Bot. Stud. (Taipei, Taiwan) 47:61-69.

Ebdon, J.S. and K.L. Kopp. 2004. Relationships between water use efficiency, carbon isotope discrimination, and turf performance in genotypes of kentucky bluegrass during drought. Crop Sci. 44:1754-1762.

Ebdon, J.S., A.M. Petrovic, and R.W. Zobel. 1998. Stability of evapotranspiration rates in kentucky bluegrass cultivars across low and high evaporative environments. Crop Sci. 38:135142.

Elbersen, H.W. and C.P. West. 1996. Growth and water relations of field-grown tall fescue as influenced by drought and endophyte. Grass Forage Sci. 51:333-342.

Githinji, L.J.M., J.H. Dane, and R.W. Walker. 2009. Water-use patterns of tall fescue and hybrid bluegrass cultivars subjected to ETbased irrigation scheduling. Irrig. Sci. 27:377391

Hays, K.L., J.F. Barber, M.P. Kenna, and T.G. McCollum. 1991. Drought avoidance mechanisms of selected bermudagrass genotypes. HortScience 26:180-182.

Hopkins, A.A. and S. Bhamidimarri. 2009. Breeding summer-dormant grasses for the United States. Crop Sci. 49:2359-2362.

Huang, B., J. Fry, and B. Wang. 1998a. Water relations and canopy characteristics of tall fescue cultivars during and after drought stress. HortScience 33:837-840.

Huang, B., X. Liu, and J.D. Fry. 1998b. Shoot physiological responses of two bentgrass cultivars to high temperature and poor soil aeration. Crop Sci. 38:1219-1224.

Huang, B. and H. Gao. 2000. Root physiological characteristics associated with drought resistance in tall fescue cultivars. Crop Sci. 40:196203.

Jiang, Y. and B. Huang. 2000. Effects of drought or heat stress alone and in combination of kentucky bluegrass. Crop Sci. 40:13581362.

Jiang, Y. and B. Huang. 2001a. Drought and heat stress injury to two cool-season turfgrasses in relation to antioxidant metabolism and lipid peroxidation. Crop Sci. 41:436-442.

Jiang, Y. and B. Huang. 2001b. Physiological responses to heat stress alone or in combination with drought: A comparison between tall fescue and perennial ryegrass. HortScience 36:682-686.

Kirda, C. and R. Kanber. 1999. Water, no longer a plentiful resource, should be used sparingly in irrigation agriculture. In: Kirda, C., P. Moutonnet, C. Hera, and D.R. Nielsen (eds.). Crop yield responses to deficit irrigation. Kluwer, Dordrecht, The Netherlands.

Krause, H.G. and E. Weis. 1984. Chlorophyll fluorescence as a tool in plant physiology. II. 
Interpretation of fluorescence signals. Photo. Res. 5:139-157.

Marcum, K.B. 1998. Cell membrane thermostability and whole-plant heat tolerance of kentucky bluegrass. Crop Sci. 38:12141218.

Malinowski, D.P., H. Zuo, B.A. Kramp, J.P. Muir, and W.E. Pinchak. 2005. Obligatory summerdormant cool-season perennial grasses for semiarid environments of the southern great plains. Agron. J. 97:147-154.
Perdomo, P., J.A. Murphy, and G.A. Berkowitz. 1996. Physiological changes associated with performance of kentucky bluegrass cultivars during summer stress. HortScience 31:11821186.

Taiz, L. and E. Zeiger. 2002. Plant physiology. Sinauer Associates, Sunderland, MD.

Turgeon, A.J. 1980. Turfgrass management. Reston Pub., Reston, VA.

Turgeon, A.J. 2005. Turfgrass management. Prentice Hall, Upper Saddle River, NJ.
Wang, J.Z., L.J. Cui, Y. Wang, and J.L. Li. 2009. Growth, lipid peroxidation and photosynthesis in two tall fescue cultivars differing in heat tolerance. Biol. Plant. 53:237-242.

West, C.P. 1994. Physiology and drought tolerance of endophyte infected grasses. CRC Press, Boca Raton, FL.

Zhang, X., E.H. Ervin, and R.E. Schmidt. 2003. Plant growth regulators can enhance the recovery of kentucky bluegrass sod from heat injury. Crop Sci. 43:952-956. 